\title{
THE EFFECT OF RELIGIOUS UNDERSTANDING OF ISLAMIC EDUCATION STUDENTS ON SCIENTIFIC WRITING ETHICS
}

\author{
Yulina Faoziah ${ }^{1}$, Imam Mudjiono ${ }^{2}$, \\ Universitas Islam Indonesia \\ imam.mudjiono@uii.ac.id
}

\begin{abstract}
Religiosity is a benchmark for studying religion. In doing scientific work, students need to pay attention to the ethics of writing scientific papers. but some students do not understand writing and want an instant way to be able to quote sentences without including the author's name. This study aims to determine the level of influence of religiosity on the ethics of writing scientific papers for students of the 2017 Islamic Religious Education Study Program, Faculty of Islamic Studies, Islamic University of Indonesia. This type of research is field research with a quantitative approach. The object of this research is Religiosity $(\mathrm{X})$ and Ethics of Scientific Writing $(\mathrm{Y})$. In addition, this study used 41 random samples from 161 students, while to analyze the level of influence of religiosity on the ethics of scientific writing using simple linear regression analysis techniques. Based on the results of research and data analysis with simple linear regression analysis calculations, the results are the magnitude of the influence of religiosity R 0.573 obtained R Square of 0.328 or $32.8 \%$ and $67.2 \%$ influenced by other factors such as lack of socialization, poor understanding of scientific writing, lack of supervision, technological progress, student laziness, negative attitude, so that it can be concluded that the influence of religiosity on the ethics of writing scientific papers for students of the 2017 Islamic Religious Education Study Program, Faculty of Islamic Studies, Islamic University of Indonesia by $32.8 \%$ is influenced by religiosity factors.
\end{abstract}

Keywords: Religiosity, Ethics of writing scientific papers, Islamic Education

\begin{abstract}
Abstrak
Religiusitas menjadi tolak ukur mendalami agama. Dalam mengerjakan karya ilmiah mahasiswa perlu memperbatikan etika penulisan karya ilmiah. tetapi sebagian mahasiswa belum memahami penulisan dan menginginkan cara instant untuk dapat mengutip kalimat dengan tidak mencantumkan nama pengarang. Penelitian ini bertujuan untuk mengetabui tingkat pengarub religiusitas terhadap etika menulis karya ilmiah bagi mahasiswa Program Studi PAI 2017 FIAI UII. Jenis penelitian ini adalah penelitian lapangan dengan pendekatan kuantitatif. Objek penelitian ini adalah Religiusitas $(X)$ dan Etika Karya Tulis Ilmiah (Y). Selain itu, penelitian ini menggunakan 41 sampel acak dari 161 mahasiswa, sedangkan untuk menganalisis tingkat pengarub religiusitas terbadap etika penulisan ilmiah menggunakan teknik analisis regresi linier sederbana. Berdasarkan basil penelitian dan analisis data dengan perbitungan analisis regresi linier sederbana yaitu besarnya pengaruh religiusitas $\mathrm{R}$ 0,573 diperoleh $\mathrm{R}$ Square sebesar 0,328 atau 32,8\% dan 67,2\% dipengarubi oleh faktor lain seperti kurangnya sosialisasi, pemahaman penulisan karya ilmiah kurang baik, kurangnya pengawasan, kemajuan teknologi, sikeap malas mahasiswa, sikeap negatif, sehingga dapat disimpulkan bahwa pengaruh religiusitas terbadap etika penulisan karya ilmiah
\end{abstract}


mabasiswa Program Studi Pendidikan Agama Islam Angkatan 2017 Fakultas Ilmu Agama Islam Universitas Islam Indonesia sebesar 32,8\% dipengarubi oleh faktor religiusitas.

Kata Kunci: Religiusitas, Etika Penulisan Karya Ilmiah, Pendidikan Islam.

\section{INTRODUCTION}

Religiosity is an individual's understanding of belief in religion, in carrying out worship and living the religion adopted, a person will be able to reach the point of religiosity when the foundation of belief in religion is firmly planted so that someone can be said to be pious. Meanwhile, according to GlokStark in his book Djamaludin Ancok, religion is a system of symbols, belief systems, value systems, and systems of institutionalized behavior, all of which are centered and can be lived as the ultimate meaning. Moreover, someone who has strong faith, will believe in the existence of God and his religion. For example, when a student is going to work on a scientific paper, he will certainly quote some of the theories he discusses through books.

In the book entitled "Jogja Academics Underground" written by Hujair AH. Sanaky said that the honesty of students in Jogja itself is still using instant ways to take the thesis. In Jogja itself there are various businesses of Thesis Guidance Bureau that serve in various departments except engineering. There are several fundamental reasons students choose to use the services of Thesis Guidance ranging from no similar themes, differences in methods, lecturers who killer and often go out of town, etc. This is what makes the decline in the value of honesty, students stuck to instant results, decreased fighting power, and advances in information technology that make all things easy to access. So it is necessary to strengthen academic culture, the tradition of writing scientific works including the use of a code of ethics, as well as the involvement of students in research so as to be an antidote to the rise of the Thesis Guidance Bureau ${ }^{1}$. In addition to the thesis bureau, plagiarization itself is increasingly rampant and the culprit is not only among students but penetrates the world of teachers with various modes. Consciously, plagiarization efforts are as tangible evidence of one's inability to make thesis, thesis, scientific works, articles, etc. so that in order to fulfill the final goal in various ways will be done to complete the scientific work ${ }^{2}$.

Writing scientific papers, one must have the ethics of writing scientific papers when citing journals or books. Someone who wants to do research is expected to be able to use the ethics of writing scientific papers as a guide in making scientific papers. The ethics of writing scientific papers is permission or courtesy in citing someone's work. When someone quotes a book without changing the words, it is plagiarism. The problem of plagiarism is not a simple problem but is closely related to understanding the purpose of citing (when do we need to quote) which is basically related to understanding the purpose of reviewing literature. Plagiarism is an act of taking other people's ideas, ideas or works to be recognized as one's own work without including the source so that it will lead to wrong assumptions about the origin of an idea or work ${ }^{3}$. In his book, Gunawan Wiradi, entitled "Ethics of Scientific Writing" plagiarism according to the term comes from Latin, namely plagiarius which means

\footnotetext{
${ }^{1}$ Hujair AH Sanaky, Jogja Academics Underground (Yogyakarta: Kukaba, 2012), 115.

2 Ana Zumetti and Roni Efendi, "Plagiat Sebagai Bentuk Pelanggaran Akademik Dalam Paradigma Teori Property," Jurnal Normative 6 No.2 (2018).

${ }^{3}$ Henry Soelistyo, Plagiarisme: Pelanggaran Hak Cipta dan Etika (Yogyakarta: Kanisius, 2011), 21.
} 
kidnapping or stealing manuscripts. In Indonesian the word plagiarism comes from the Dutch language, namely letterdief which means literary thief. Plagiarism can be used to designate the person who did it, the action taken and the result of the action taken. Scientifically, the stolen goods are not physical, but what is stolen is an idea that is written as a paper. According to the General Indonesian Dictionary (KUBI) by W.J. S. Poerwadarminta (1982) said plagiarism is taking or taking an essay from another person and published as one's own work ${ }^{4}$. If a researcher plagiarizes, it means that the person's level of religiosity is still low because it has not been used as a guide in compiling a scientific work.

Campus environment still has students who only make works by copying and pasting other people's work which causes their selves to not be able to fully understand their own work. There are also students who only take from the internet without including the website address taken. This can be said to be a plagiarism without going through a permit yet some students admit that the results are their own work. For example, when a lecturer gives an assignment to make a scientific paper and it has to be checked by plagiarism checkers first so it can be seen which students are really working seriously or just copy and paste. There are still many students who have not realized the error and it will cause students to repeat mistakes in writing scientific papers.

After being identified from the experience on campus, there are some students who still do not understand the ethics of writing scientific papers when making it. Some of the students want an instant way to be able to quote a sentence by not including the name of the author who is quoted so that plagiarism will occur in writing scientific papers. In addition, students still do not understand thesis writing techniques. It is better for students to learn more about thesis writing techniques so they can apply it in making reports or scientific works. Moreover, if a student has a high level of religiosity, he will not commit fraud such as copying and pasting, not including the author's name, not violating patents and institutional rights because he understands manners in writing scientific papers and applies thesis writing techniques. Students should be able to create their own scientific work based on the ethics of writing scientific papers that have been understood. Departing from this problem, the researcher is interested in studying further about "The Influence of Religiosity on the Ethics of Scientific Writing for Students of the 2017 Islamic Education Study Program, Faculty of Islamic Studies, Islamic University of Indonesia". Thus, as students and the community should be able to use and utilize this research as a reference for making scientific works.

\section{METHOD}

This study is part of the correlation because it aims to determine the level of influence of student religiosity on the ethics of writing scientific papers. The subjects in this study were students of the Islamic Religious Education Study Program, Faculty of Islamic Religion, Islamic University of Indonesia in $2017^{5}$. The objects in this study were Religious and Scientific Writing Ethics. This research was conducted at the Integrated Campus of the Indonesian Islamic University, Faculty of Islamic Studies. This study chose to use a random

\footnotetext{
58.

${ }^{4}$ Gunawan Wiradi, Etika Penulisan Karya Ilmiah, Cet. IV (Jakarta: Yayasan Pustaka Obor Indonesia, 2020), 12${ }^{5}$ Sugiyono, Metode Penelitian Kuantitatif, Kualitatif dan R\&D (Bandung: Alfabeta, 2016), 7.
} 
sample to distance researchers from subjective feelings because they do not prioritize respondents. The population in this study were all students of the Islamic Religious Education Study Program, Faculty of Islamic Religion, Islamic University of Indonesia in 2017, totaling 161 students, taking a sample of 41 students with the calculation $\frac{25}{100} \times 161=40.25$ rounded up to 41. This research instrument uses a questionnaire, with this research technique using a Likert scale. Data analysis in this study using simple linear regression and frequency distribution.

\section{RESULT}

\section{Preparation phase}

First of all, which was prepared before conducting the actual research, the researcher conducted a questionnaire test or often called a try out. A try out was conducted to test the validity and reliability of a questionnaire, with 20 students majoring in Islamic Religious Education Class 2017 as test respondents on Thursday, November 26, 2020.

The validity testing is using the SPSS version 22 program. The results of the validity test on the religiosity variable $(\mathrm{X})$ from 15 valid data items were 13 items, 2 items were considered invalid, while the invalid numbers were numbers 4 and 5 . Whereas, on the ethical writing variable $(Y)$ of the 20 valid items there are 18 items valid and 2 are considered invalid, namely numbers 5 and 10 are declared invalid. Invalid items may be caused by questions that are made less clear so respondents were confused about giving answers, besides that the respondents' answers are inconsistent. In dealing with invalid items, it is possible to correct the questions in the questionnaires that fall and then redistribute them to the respondents, then invalid question items can also be removed by discarding them. ${ }^{6}$

It is stated by determining the validity based on rTable at the significance level $5 \%$ with the number $\mathrm{N}=20$ and rTabel 0,444. Doubt the statement item with a total score $<$ 0,444 then the item of the statement in the instrument is considered invalid or omitted, while if the item of the statement with a total score $>0,444$ then the statement items in the instrument are declared valid.

Then the realibity test is a requirement for testing the validity of the instrument although a valid instrument in general must be reliable but reliability testing needs to be done to find out if the data is reliable or not ${ }^{7}$.

\section{Reliability test}

Tabel 1. Realiability Test

\begin{tabular}{cccc}
\hline Variable & rTable & rCount & Information \\
\hline Religiosity & 0,444 & 0,891 & Reliable \\
& & & \\
Ethics of & 0,444 & 0,906 & Reliable \\
Scientific & & & \\
Writing & & & \\
\hline
\end{tabular}

${ }^{6}$ Sahid Raharjo, "Cara Mengatasi Soal Angket yang Tidak Valid", dikutip dari https:// www.konsistensi.com/2014/03/mengatasi-angkettidak-valid.html?m=1 diakses tanggal 14 Juni 2021.

${ }^{7}$ Eko Putro Widoyoko, Teknik Penyusunan Instrumen Penelitian (Yogyakarta: Pustaka Pelajar, 2018), 15-158. 
From the table above, it can be concluded that the determination of reliability is based on $r$ Table at a significance level of $5 \%$ with the number $\mathrm{N}=20$, rTable 0.444 while the results of the reliability calculation on the religiosity variable are 0.891 and the ethics of writing scientific papers are 0.906. It is said that this instrument is declared reliable and can used for further research.

\section{Implementation Stage}

The next stage is the implementation or retrieval of research data by distributing questionnaires to be asked to respondents about the religiosity and ethics of writing scientific papers. The sample used in this study was 41 students of Islamic Religious Education Class 2017. The distribution of this questionnaire was carried out on November 27, 2020 to November 28, 2021.

\section{Assumption test}

\section{Normality test}

Based on the data analysis, this normality test uses one sample kolmogrov SPSS 22 for windows, with the number of respondents as many as 41 students of the 2017 Islamic Religious Education Program.

Tabel. 2. Normaly test

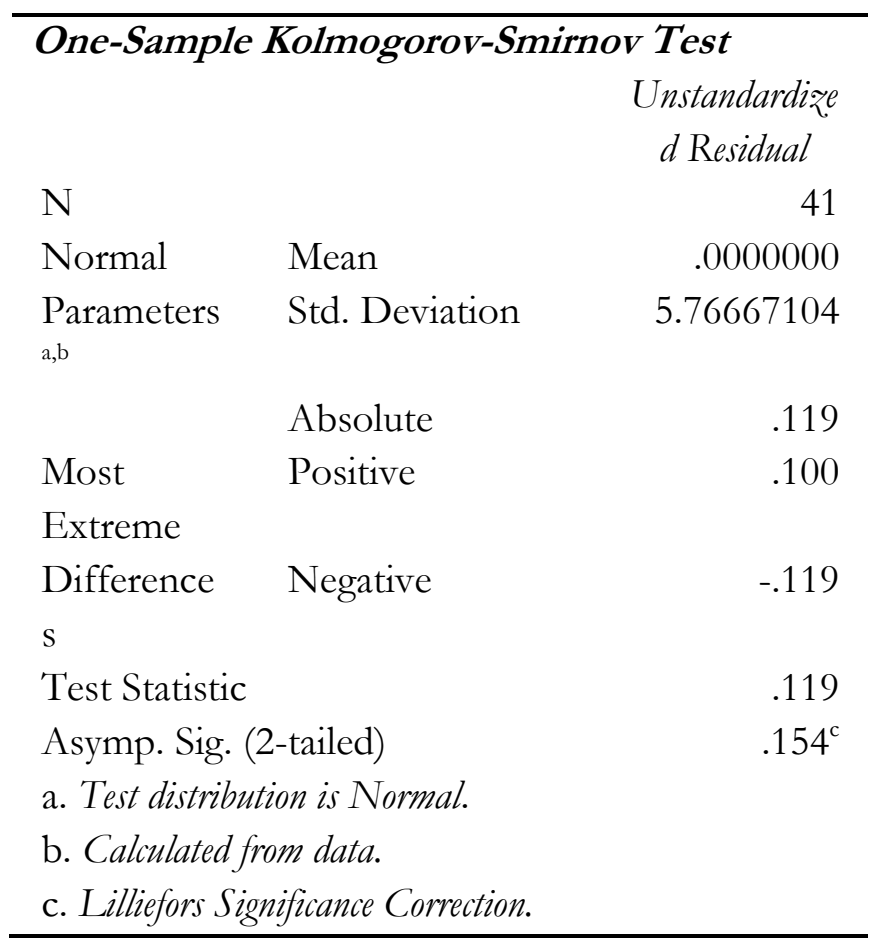

Based on the table above, the results of the normality test on the two variables, namely Religiosity $(\mathrm{X})$ and Ethics of Scientific Writing (Y), the significance value is 0,154 > 0,05 it can be concluded that the residual value is normally distributed. 


\section{Linearity Test}

The linearity test has a purpose to determine the relationship between two variables that are linearly significant or not. Conditions can be expressed linearly if $\mathrm{p}>0.05$ or if Fhitung $<$ Ftabel then there is a significant linear relationship between the free variable $(\mathrm{X})$ and the bound variable $(Y)^{8}$. The results of the linearity test using SPSS 22 for windows are as follows:

Tabel. 3. Anova test

\begin{tabular}{|c|c|c|c|c|c|c|c|}
\hline \multicolumn{8}{|c|}{ ANOVA Table } \\
\hline & & & Sum of & $\mathrm{df}$ & Mean & $\mathrm{F}$ & Sig. \\
\hline & & & Squares & & Square & & \\
\hline \multirow{4}{*}{$\begin{array}{l}\text { Ethics of } \\
\text { Scientific } \\
\text { Writing } \\
\end{array}$} & Between & (Combined) & 1113.93 & 14 & 79.567 & 2. & .02 \\
\hline & Groups & & 8 & & & 38 & 7 \\
\hline & & & & & & 9 & \\
\hline & & Linearity & 649.625 & 1 & 649.62 & 19 & .00 \\
\hline \multirow[t]{8}{*}{ Religiosity } & & & & & 5 & .5 & 0 \\
\hline & & & & & & 07 & \\
\hline & & Deviation & 464.313 & 13 & 35.716 & 1. & .42 \\
\hline & & from & & & & 07 & 2 \\
\hline & & Linearity & & & & 2 & \\
\hline & \multirow{3}{*}{\multicolumn{2}{|c|}{ Total }} & 865.867 & 26 & 33.303 & & \\
\hline & & & 1979.80 & 40 & & & \\
\hline & & & 5 & & & & \\
\hline
\end{tabular}

Based on the linearity test table above, it shows that the significance value contained in the deviation from linearity line is $0,422>0,05$ then it can be said to have a relationship with the variable religiosity $(\mathrm{X})$ on the ethical variable of writing scientific papers $(\mathrm{Y})$.

\section{Research Result Test}

\section{Frequency Distribution Test}

Religiosity Variable Frequency Distribution Test

\begin{tabular}{|l|r|r|r|l|l|}
\hline KATEGORI & \multicolumn{2}{|l|}{ RENTANG } & N & & $\%$ \\
\hline TIDAK RELIGIUS & 15 & 30 & 0 & & 0 \\
\hline BELUM RELIGIUS & 31 & 45 & 0 & & 0 \\
\hline BELAJAR RELIGIUS & 46 & 60 & 12 & & 29,27 \\
\hline RELIGIUS & 61 & 75 & 29 & & 70,73 \\
\hline
\end{tabular}

The table above can be determined that the high level of religiosity of students of the 2017 Islamic Religious Education Study Program, Faculty of Islamic Studies, Islamic University of Indonesia is $70.73 \%$. Test of Frequency Distribution of Scientific Writing Ethics Variables

\begin{tabular}{|l|r|r|r|r|}
\hline KATEGORI & \multicolumn{2}{|c|}{ RENTANG } & N & $\%$ \\
\hline TIDAK BER-ETIKA & 20 & 40 & 0 & 0 \\
\hline BELUM BER-ETIKA & 41 & 60 & 0 & 0 \\
\hline BELAJAR BER-ETII & 61 & 80 & 9 & 21,9512195 \\
\hline BER-ETIKA & 81 & 100 & 32 & 78,0487805 \\
\hline
\end{tabular}

\footnotetext{
${ }^{8}$ Sugiyono, Statistik. Untuk Penelitian (Bandung: Alfabeta, 2016), 265.
} 
From the table above, it can be determined that the high level of ethics in writing scientific papers for students of the 2017 Islamic Religious Education Study Program, Faculty of Islamic Studies, Islamic University of Indonesia, is $78.1 \%$.

\section{Simple Linear Regression Analysis Technique}

The requirements for the simple linear regression test are used after going through the validity, reliability, normality, and linearity tests. It is said to be normal, then a simple linear regression test can be performed. While the requirements to determine the level of magnitude by looking at the value of $\mathrm{R}$ Square. In a simple linear regression test is using the help of SPSS version 22 for windows.

Tabel. 4 Linear Regression Analysis Technique

\begin{tabular}{|c|c|c|c|c|}
\hline \multicolumn{5}{|c|}{ Model Summary $^{b}$} \\
\hline $\begin{array}{l}\text { Mo } \\
\text { del }\end{array}$ & $\mathrm{R}$ & $\begin{array}{c}\mathrm{R} \\
\text { Squ } \\
\text { are }\end{array}$ & $\begin{array}{l}\text { Adjust } \\
\text { ed R } \\
\text { Square }\end{array}$ & $\begin{array}{l}\text { Std. Error of } \\
\text { the Estimate }\end{array}$ \\
\hline 1 & $\begin{array}{r}.5 \\
73 \\
a\end{array}$ & $\begin{array}{r}.32 \\
8\end{array}$ & .311 & 5.840 \\
\hline \multicolumn{5}{|c|}{$\begin{array}{l}\text { a. Predictors: (Constant), Religiosity } \\
\text { b. Dependent V ariable: Ethics of Scientific } \\
\text { Writing }\end{array}$} \\
\hline
\end{tabular}

Based on the output, the correlation value or $\mathrm{R}$ relationship is 0.573 . The coefficient of determination (R Square) is 0.328 which implies that the level of influence of religiosity $(\mathrm{X})$ on the ethics of writing scientific papers $(\mathrm{Y})$ is $32.8 \%$ and $67.2 \%$ influenced by other factors.

After a simple linear regression test was carried out, it could answer the hypothesis which had been formulated above with the statement that $\mathrm{Ha}$ was accepted "There is an influence between religiosity on the ethics of writing scientific papers for students of the Faculty of Islamic Studies, Islamic Religious Education Study Program Class of 2017 of $32.8 \% "$.

\section{DISCUSSION}

Religiosity is a person's understanding of the religion he believes in so that he can live the religion and implement it in everyday life. A person's ability to understand, appreciate, and apply the noble values of the religion he adheres to in everyday life can be said to be religious maturity because it can be seen from his ability. Through a questionnaire that was distributed to respondents on Friday, November 27, 2020 there were several respondents who gave different answers. One of it was a statement about the act of cheating when doing something. There are 3 respondents who answered hesitantly $(R G)$ in committing fraud when doing something. Furthermore, the statement about liking to do things through an instant method, there are 11 respondents who answered doubtful (RG) and 1 respondent answered agree (S). It means that there are still students who cheat through instant ways when doing something. 
From the theory according to Djamaludin Ancok, one of the dimensions of feeling or appreciation (the experience dimension) is a religious feeling that has been experienced and felt such as feeling close to God, peaceful when praying, being touched by hearing scriptures, feeling afraid to sin, feeling happy that his prayer is being answered, etc ${ }^{9}$. Then from these various dimensions the religious structure of the individual leads to what Vergote calls religious "attitudes". A person who has a religious attitude is one who knowingly and willingly personally accepts and approves of the religious images that have been passed down to him by society and which he makes his own, his personal beliefs, the faith of inner beliefs that he creates in everyday behavior. The individual's approval of the religious "heritage" does not take place without a continuous purification process of religious feelings and religious motivations that exist in the heart of the person concerned ${ }^{10}$. Therefore, in order to equip yourself and maintain the quality of faith, every mukallaf has an obligation to understand the nature of Islam and its scope correctly. If the understanding and commitment is correct to the Islamic creed then it can be a guide for every mukallaf in behaving ${ }^{11}$. Therefore from the field data and theory it can be concluded that there are still students who are not afraid of committing fraud and sin. Whereas in this dimension, it has been explained that someone who can live in religious way is able to feel fear of sinning, close to God, and so on.

A person obeys to a certain religion because he thinks that religion is the greatest so he will try to be a good follower. This belief is displayed in religious attitudes and behaviors that reflect obedience to religion. On the other hand, a person's religious attitude is influenced by the background and various religious experiences and personality types of each ${ }^{12}$. Therefore religiosity is important to be instilled in a person. In the campus environment, students often get assignments such as making scientific papers, where in making scientific works students must be honest and pay attention to the ethics of writing scientific papers. Ethics in writing scientific papers can be interpreted as courtesy or permission in citing someone's work. Experience on campus, there are some students who still do not understand the ethics of writing scientific papers when making it. Some of the students want an instant way to be able to quote a sentence by not including the name of the author they quoted so that plagiarism will occur in writing scientific papers. In addition, students still do not understand the technique of writing thesis. Therefore, if a student has a high level of religiosity, he will not commit fraud such as copying and pasting, not including the author's name, not violating patents and institutional rights because he understands manners in writing scientific papers and applies thesis writing techniques.

Hence, research was carried out through the distribution of questionnaires that had been carried out to 41 respondents on Friday, November 27, 2020 from several statements, one of it was based on patent rights when conducting research, there were 6 respondents who gave a hesitant answer $(R G)$ then a statement about cheating when making scientific papers in the form of copy and pasting via the internet, there were 8 respondents who answered

\footnotetext{
${ }^{9}$ Djamaludin Ancok, Psikologi Agama (Yogyakarta: Pustaka Pelajar, 2005), 77-80.

${ }^{10}$ Nico Syukur Dister, Psikologi Agama (Jakarta: Kanisius, 1989), 10.

${ }^{11}$ Kementerian Agama Republik Indonesia, Buku Siswa Akidah Akblak Madrasah Aliyah Kelas X (Jakarta: Kementerian Agama, 2014), 180-81.

12 Jalaluddin, Psikologi Agama (Jakarta: Rajawali Press, 2005), 19.
} 
undecided (RG). It is possible that there are still students who only copy and paste raw from the internet without being reprocessed. According to Gunawan's theory, if someone writes a scientific paper and uses other people's ideas, it should be clear by mentioning the source accompanied by justified writing procedures. Thus, this must be fulfilled to avoid lawsuits as plagiarists or hijackers ${ }^{13}$. Based on experience on campus and theory, it can be concluded that there are still some students who violate the ethics of writing scientific papers. Students should be able to create their own scientific work based on the ethics of writing scientific papers that have been understood. There are several steps to avoid plagiarism such as paraphrasing and summarizing, always listing the original source or using direct quotations when using original phrases ${ }^{14}$.

The researcher is interested in conducting research on "The Influence of Religiosity on the Ethics of Writing Scientific Work for Students of the 2017 Islamic Religious Education Study Program Faculty of Islamic Studies, Islamic University of Indonesia" through sample calculations guided by Suharsimi Arikunto's theory that samples can be taken between $10 \%$ $15 \%$ to $20 \%-25 \%$ or even more than $25 \%$ of the total population ${ }^{15}$. The population in this study was all students of the 2017 Islamic Education Study Program, Faculty of Islamic Studies, Islamic University of Indonesia, totaling 161 students. This study took a sample of 41 students with the calculation of $\frac{25}{100} \times 161=40,25$ rounded to 41 .

Through data processing the results of questionnaires or questionnaires that have been made and distributed to all respondents, namely all students of the 2017 Islamic Religious Education Study Program by taking a sample of 41 respondents, to find results and answer the research problem formulation, namely to determine the magnitude of the influence of the religiosity variable $(\mathrm{X})$ on the ethical variable of writing scientific papers $(\mathrm{Y})$. After knowing the sample then looking for the level of validity based on Tukiran's opinion that the validity test is a level of legitimacy test. A valid instrument will have high validity and vice versa, an instrument that is less valid means it has low validity ${ }^{16}$. The results of the validity test using SPSS 22 can be seen on the religiosity variable $(\mathrm{X})$ of the 15 valid data items as many as 13 items, 2 items are considered invalid, while the invalid numbers are numbers 4 and 5 . Meanwhile, the ethical variable for writing scientific papers $(Y)$ of 20 items is 18 valid items, 2 are considered invalid, there are numbers 5 and 10 are declared invalid. In this statement, it is evidenced by the determination of validity based on rTable at a significance level of $5 \%$ with the number of $\mathrm{N}=20$ and rTable 0.444 . For reliability testing, it is a requirement for testing the validity of the instrument, although valid instruments are generally reliable, but reliability testing needs to be done ${ }^{17}$. The results of the reliability test are based on the rTable at the $5 \%$ significance level with the number $\mathrm{N}=20$, the rTable 0.444 while the results of the reliability calculation on the religiosity variable are 0.891 and the ethics of writing scientific papers are 15.

${ }^{13}$ Gunawan Wiradi, Etika Penulisan Karya Ilmiah, Cet.IV (Jakarta: Yayasan Pustaka Obor Indonesia, 2020), 11-

${ }^{14}$ Muhammad Abdan Shadiq, "Memahami dan Mencegah Perilaku Plagiarisme Dalam Menulis Karya Ilmiah," Jurnal Universitas Gajah Mada 27 No.1 (2019).

${ }^{15}$ Suharsimi Arikunto, Prosedur Penelitian Suatu Pendekatan Praktik, Cet 13 (Jakarta: Rineka Cipta, 2006), 112.

16 Tukiran Taniredja and Hidayati Mustafidah, Penelitian Kuantitatif (Sebuab Pengantar) (Bandung: Alfabeta, 2011), 42.

17 Widoyoko, Teknik Penyusunan Instrumen Penelitian, 15-158. 
0.906 so it can be concluded that this instrument is declared reliable and can be used for further research.

After going through the validity and reliability test, then linearity test and normality test were carried out. This normality test can be obtained that the data used is normally distributed or not with the requirements if sig rcount $>0,05$ then it can be said to be normally distributed and also vice versa when sig rhitung $<0,05$ then it is said to be non-normally distributed. The results of the normality test, namely Religiosity $(\mathrm{X})$ and Scientific Writing Ethics $(\mathrm{Y})$, the significance value is $0,154>0,05$ it can be concluded that the residual value is normally distributed. Linear test is one of the assumptions of the regression with the requirement that if it is not linear then the linear regression analysis cannot be continued. The condition can be said to be linear when $\mathrm{p}>0,05$ or if Fcount $<$ Ftable then there is a significant linear relationship between the independent variable $(\mathrm{X})$ and the dependent variable $(\mathrm{Y})^{18}$. The results of the linearity test of the significance value contained in the deviation from linearity line are $0,422>0,05$ then it can be said to have a relationship with the variable religiosity $(X)$ on the ethical variable of writing scientific papers $(\mathrm{Y})$. Furthermore, to find out the high level of religiosity and high ethical writing of scientific papers using a frequency distribution test which is based on the theory according to Anas Sudijono that the frequency distribution is a condition that describes how the frequency of symptoms or variables is represented by numbers, has been distributed, divided or scattered ${ }^{19}$. Based on calculations using SPSS, the high level of religiosity is $70.73 \%$, while the high ethical writing of scientific papers is $78.1 \%$. To determine the level of influence using simple linear regression analysis, the researcher uses the opinion of Muhammad Iqbal Hasan that simple linear regression analysis is a linear regression that only involves two variables, namely one independent variable $(\mathrm{X})$ and one dependent variable $(Y)^{20}$. The requirements for the simple linear regression test are that after going through the validity, reliability, normality, and linearity tests, it is said to be normal, then a simple linear regression test can be performed requirements to know the magnitude by looking at the R Square value. The results of simple linear regression analysis, namely the level of influence of religiosity $\mathrm{R}$ of 0.573 , obtained a coefficient of determination (R Square) of 0.328 which implies that the level of influence of religiosity $(\mathrm{X})$ on the ethics of writing scientific papers $(\mathrm{Y})$ is $32.8 \%$.

It can be said that $\mathrm{Ha}$ is accepted, meaning that the magnitude of the influence of the religiosity variable $(\mathrm{X})$ on the ethical variable of writing scientific papers $(\mathrm{Y})$ students of the 2017 Islamic Religious Education Study Program Faculty of Islamic Studies is 32.8\% and $67.2 \%$ is influenced by other factors such as lack of socialization, understanding of writing scientific papers is not good, lack of supervision, technological progress, lazy attitude of students, and negative attitude.

\footnotetext{
${ }^{18}$ Sugiyono, Statistik Untuk Penelitian, 265.

19 Anas Sudijono, Pengantar Statistik Penelitian (Jakarta: Raja Grafindo Persada, 2014), 37.

${ }^{20}$ M. Iqbal Hasan, Pokok-Pokok Materi Statistik 1 (Jakarta: Bumi Aksara, 1999), 246.
} 


\section{CONCLUSION}

Based on the results of research and data analysis, it can be concluded that calculating the level of religiosity of students of Islamic Religious Education at the Islamic University of Indonesia is high, the ethics of writing scientific papers for students of Islamic Religious Education at the Islamic University of Indonesia is high, while the level of influence of religiosity on the ethics of writing scientific papers is 0.328 or $32.8 \%$ while $67.2 \%$ is influenced by other factors such as lack of socialization, poor understanding of scientific writing, lack of supervision, technological progress, lazy attitude of students, negative attitude then $\mathrm{Ha}$ is accepted and $\mathrm{Ho}$ is rejected, which means that there is an influence between religiosity on the ethics of writing scientific papers for students of the 2017 Islamic Religious Education Study Program, Faculty of Islamic Studies, Islamic University of Indonesia.

\section{REFERENCES}

Ancok, Djamaludin. Psikologi Agama. Yogyakarta: Pustaka Pelajar, 2005.

Arikunto, Suharsimi. Prosedur Penelitian Suatu Pendekatan Praktik. Cet 13. Jakarta: Rineka Cipta, 2006.

Benso, S., \& Schoroeder, B. (2009). Ethics of Writing. New York Press: State University of New York Press.

Dister, Nico Syukur. Psikologi Agama. Jakarta: Kanisius, 1989.

Hasan, M. Iqbal. Pokok-Pokok Materi Statistik 1. Jakarta: Bumi Aksara, 1999.

Jalaluddin. Psikologi Agama. Jakarta: Rajawali Press, 2005.

Kementerian Agama Republik Indonesia. Buku Siswa Akidah Akblak Madrasah Aliyah Kelas X. Jakarta: Kementerian Agama, 2014.

Longfellow, E. (2004). Women and Religious Writing in Early Modern England. New York: Cambridge University Press.

Myers, K. A. (2000). Crossing Boundaries: Defining the Field of Female Religious Writing in Colonial Latin America. Colonial Latin American Review, Vol. 9, No. 2.

Robinson, F. (1993). Technology and Religion Change: Islam and the Impact of Print. Modern Asian Studies, Vol,27, No.1.

Sanaky, Hujair AH. Jogja Academics Underground. Yogyakarta: Kukaba, 2012.

Shadiq, Muhammad Abdan. "Memahami dan Mencegah Perilaku Plagiarisme Dalam Menulis Karya Ilmiah.” Jurnal Universitas Gajah Mada 27 No.1 (2019).

Soelistyo, Henry. Plagiarisme: Pelanggaran Hak Cipta dan Etika. Yogyakarta: Kanisius, 2011.

Stroumsa, G. G. (2016). Religious memory, between orality and writing. Memory Studies, Vol.9 No.3.

Sudijono, Anas. Pengantar Statistik Penelitian. Jakarta: Raja Grafindo Persada, 2014.

Sugiyono. Metode Penelitian Kuantitatif, Kualitatif dan R\&D. Bandung: Alfabeta, 2016. Statistik Untuk Penelitian. Bandung: Alfabeta, 2016.

Taniredja, Tukiran, and Hidayati Mustafidah. Penelitian Kuantitatif (Sebuah Pengantar). Bandung: Alfabeta, 2011.

Widoyoko, Eko Putro. Teknik Penyusunan Instrumen Penelitian. Yogyakarta: Pustaka Pelajar, 2018. 
Yulina Faoziah, Imam Mudjiono

Wiradi, Gunawan. Etika Penulisan Karya Ilmiah. Cet. IV. Jakarta: Yayasan Pustaka Obor Indonesia, 2020.

- Etika Penulisan Karya Ilmiah. Cet.IV. Jakarta: Yayasan Pustaka Obor Indonesia, 2020.

Zumetti, Ana, and Roni Efendi. "Plagiat Sebagai Bentuk Pelanggaran Akademik Dalam Paradigma Teori Property.” Jurnal Normative 6 No.2 (2018). 